\title{
Access, Knowledge and Application of Public Health Law: A Case Study of Awareness of Lawyers, Medical Doctors and Nurses of Ghana's Legal Framework on Public Health
}

\author{
Ishmael D. Norman"1,2 \\ ${ }^{1}$ The Institute for Security, Disaster and Emergency Studies, Accra, Ghana \\ ${ }^{2}$ School of Public Health, University of Health and Allied Sciences, Ho, Ghana \\ Email: ishmael norman@yahoo.com
}

Received 4 December 2013; revised 1 January 2014; accepted 19 January 2014

Copyright @ 2014 by author and Scientific Research Publishing Inc.

This work is licensed under the Creative Commons Attribution International License (CC BY). http://creativecommons.org/licenses/by/4.0/

\section{(c) (i) Open Access}

\begin{abstract}
We investigated access of professionals in public health to national healthcare laws. We undertook a survey among doctors, lawyers and nurses as stand-ins for the professional class. We found that the professionals' access to public health laws was a challenge. Understanding of the legal framework on public health is needed.
\end{abstract}

\section{Keywords}

\section{Knowledge, Lawyers, Medical Doctors, Nurses, Public Health Laws}

\section{Introduction}

There appears to be a linkage between a good public health law administration exemplified by those in the western industrialized nations and the pedestrian public health law type system practiced in Sub-Sahara Africa. The correlation between understanding of public health laws by a nation's healthcare practitioners and its lawyers on one hand and the quality of its healthcare delivery services on the other hand, is a phenomenon which has not been studied by researchers in the region (Braye, Preston-Shoot et al., 2005). Considering the situation in the western industrialized nations' level of healthcare, there seems to be a relationship between the level of exposure of a nation's public health professionals to that nation's public health legal framework and the quality of services in its healthcare system, for example, the United Kingdom and the USA (Falkiner, 2003). For instance, transnational institutions such as the UNDP reports that Sub-Sahara Africa is the only region in the world regis- 
tering an increase in the under-age-five mortality rate, which has risen in Cameroon, Central Africa Republic, Chad, Congo, Kenya and Zambia. Of the 36 countries in the world with child mortality rates above 100 per 1000 births, 34 are in Sub-Sahara, followed by Afghanistan and Myanmar. The rate of the western industrialized nations is under 6 per 1000 births (UNDP, 2008). Could the rising rates of child mortality in Sub-Sahara Africa be attributable to the general lack of understanding of health laws among the populations in the region? The tapestry of Ghana's legal landscape, like many other nations within the Common Law system, is complex. It is a tapestry into which various statutes, acts, legislative and executive instruments, by-laws of municipalities, policies and regulations of ministries, departments and agencies, traditional law and the common law or judge-made law are woven (Norman, 2012). Such sources of law may not share superficial relationship with each other and may at times appear to pursue paradoxical but apposite objectives. Yet, they collectively work in consonance with the mother-law: the 1992 Constitution of Ghana.

\subsection{Public Health and Public Health Law}

The practice of public health entails both persuasive and coercive measures and policies which the health and legal professionals need to understand in order not to go against the autonomy of the people for whom the measures and policies are meant to help or protect. Public health policies may consist of documents, procedures, guiding principles, rules and regulations, statements of intent, working frameworks to achieve certain objectives, and which may not run in congruent to the constitutional guarantees against civil rights abuses. The policy may be imbedded in legislation. The policy may define the modalities for work, or contain a vision statement, a program of action, duties, responsibilities, accountability, and may sometimes contain snippets of unwritten cultural or ethical code to guide behavior. All of such may entail legal responsibilities and burdens. In all these, the ever present power of either the persuasive and coercive quality of public health policy cannot be over-emphasized. The need for the public health professionals to appreciate and understand the rubrics of applying such policies is the 'sine qua non' for dispensing healthcare in a democratic and free society. This is whether the public health policy is being applied during the interventions for contagious diseases outbreak such as Tuberculosis or during general health promotion, such as the cessation of cigarette smoking in public. Public health aims to prevent diseases, prolong life, and promote health through organized efforts of society and organizations (Winslow, 1920).

However, public health law concerns the preservation and codification of the standards established for the prevention of diseases, the prolongation of life and the promotion of health as well as the enforcement against encroachment to the legal framework affecting health and safety by regulating the conduct of society (Norman, 2011). This calls for a multi-disciplinary formation of professionals, researchers and educators as well as practitioners. In line with this notion, Dunbar in 1954 admonished the public health professional that:

"During the past century and the present one, we have relinquished as an ideal the mastery of the whole realm of human knowledge by one person, and our training as specialists has made it difficult for us to accept the ideal of intelligent cooperation... This training has tended to keep each of us so closely limited by our own field that we have remained ignorant even of the fundamental principles of the fields outside our own. This super-specialization and fragmentation are becoming increasingly problematic against the background of ongoing rapid changes in public health...” (Tetrick, 2003).

Dunbar's statement tells us that whether you are a medical doctor, a nurse or a lawyer, it is rather empowering to learn about the work of each other in order to build and contribute holistically to ensure a good public health paradigm accessible to all.

\subsection{Benefits of Skills in Law}

The combined aims of public health and public health law provide the legal framework, which requires of public health professionals such as medical doctors and nurses as well as lawyers to be literate in that framework. It further requires from each of the three cohorts mentioned, the necessity to possess a good technical knowledge of public health law and the ability to apply it in public health situations. Such a skill “... would help in identifying the moral and ethical underpinnings in the application of that knowledge as well as help define the importance of the correct application of the law..." to protect the interests and the rights of the ultimate beneficiaries of healthcare delivery and services (Braye, Preston-Shoot et al., 2005). 


\subsection{Public Access}

It is one thing to encourage medical doctors, nurses and lawyers to become conversant with public health laws, and another thing for a nation to ensure that its laws are within reason accessible to many of its citizens. The acquisition of knowledge in law is synonymous with skills gain and the enhancement of one's ability to apply it. The laws of the land are not easily accessible even to practicing lawyers, let alone, other professions. By ease of accessibility, it is meant a common source such as internet based web sites where one can download a copy of national legislation either free of charge or purchase a copy as it is in the United States, South Africa and in the EU. It appears easier for a national researcher to download copies of the US or UK or EU legislation than to even purchase on line a copy of national laws from Sub-Sahara Africa. Law is a source of empowerment and helps to make sense of competing alternatives in healthcare delivery (Johns, Braye, Preston-Shoot et al., 2005; Dickson, 1997). In order to develop a more resilient healthcare system, access to the laws of the land on health should be made available to the practitioner.

\section{Method}

Our study was stratified by profession, medical doctors, nurses and lawyers. We selected these groups of professionals because we assumed that they were part and parcel of the healthcare delivery system in Ghana and in many nations in terms of clinical work, patient care and policy development. For each group, we chose 50 respondents, bringing the total sample to 150. The total population of lawyers and doctors in Ghana is estimated to be about 3800 respectively. Many of the medical doctors are scattered in the various regions and districts, making it difficult to carry out a true random sampling at a minimal cost. Although many of the lawyers are practicing in the urban centers, they also have offices in the regions and districts. In terms of the ultimate respondents, our approach was based on random selection. We visited the various health facilities and hospitals with no pre-set idea of whom to interview. At the hospitals, we approached the medical officer on duty. If he or she agreed to be interviewed after our self introduction and the statement of the purpose of the study, then the interview proceeded. We used the same approach for the nurses. For the lawyers, we visited the various court houses within the twin Cities of Accra and Tema and randomly approached those who were clearly dressed in their professional attires of black robes and white wigs. In the grounds of the court houses, only lawyers and judges dress in such a fashion. If the respondent agreed to be interviewed after verification that he or she was a lawyer, we proceeded or moved to the next willing person where the respondent was reluctant. We did not stratify the respondents by sex or age because we were not interested in finding the correlation between sex and knowledge and awareness of public health law. We also undertook documentary review of the legal framework on health to identify their numbers and their coverage as well as accessibility. We searched the World Wide Web for health legislation on Ghana with carefully designed phrases such as "Ghana Health Service Act", "Legislative Instrument on Ghana Health Service Act", "Ghana Public Health Act” and "Ghana Health budget for 2005 through 2010" and collated the result for analysis.

\section{Results}

\subsection{Basic Demographics of Respondents}

We discovered that Ghana has a youthful professional class among the lawyers, medical doctors and the nurses as shown in Table 1 . About $52 \%$ of the respondents were within 30 - 39 age bracket, another $14.7 \%$ being within the 20 - 29 bracket and $29.3 \%$ being older within the 40 - 49 cohort. Only $2.7 \%$ of the respondents were between 50 - 59 age group.

\subsection{Accessibility to the Laws of Land}

We found that at the government printers, the list of published laws available for sale to the public had more than 250 titles consisting of various Acts, Legislative Instruments, Executive Instruments, Amendments and Policies. But in terms of accessibility to the laws of the land, and in the case of Ghana, at the start of 2012, less than $10 \%$ of Ghana's legal framework could be found on the World Wide Web. On public health law matters, the figure was less than $2 \%$. During visits to the capital cities in the Ashanti, Eastern, Central, Western, Volta, Greater Accra regions, we found that the regional libraries often did not contain catalogues or volumes of the laws forming part of the legal framework of the nation. 
Table 1. Respondents’ background.

\begin{tabular}{|c|c|c|c|c|}
\hline \multirow{2}{*}{ Characteristic } & \multicolumn{4}{|c|}{ N (\%) } \\
\hline & Lawyers & Doctors & Nurses & Total \\
\hline \multicolumn{5}{|l|}{ Age (years) } \\
\hline Mean \pm Standard deviation & $40.6 \pm 4.0$ & $38.2 \pm 4.7$ & $31.8 \pm 7.0$ & $36.8 \pm 6.5$ \\
\hline $20-29$ & $0(0.0)$ & $0(0.0)$ & $22(44.0)$ & $22(14.7)$ \\
\hline $30-39$ & $22(44.0)$ & $34(68.0)$ & $22(44.0)$ & $78(52.0)$ \\
\hline $40-49$ & $25(50.0)$ & $15(30.0)$ & $4(8.0)$ & $44(29.3)$ \\
\hline $50-59$ & $1(2.0)$ & $1(2.0)$ & $2(4.0)$ & $4(2.7)$ \\
\hline \multicolumn{5}{|l|}{ Sex } \\
\hline Female & $14(28.0)$ & $24(48.0)$ & $43(86.0)$ & $81(54.0)$ \\
\hline Male & $35(70.0)$ & $26(52.0)$ & $7(14.0)$ & $68(45.3)$ \\
\hline \multicolumn{5}{|l|}{ Education } \\
\hline Certificate & $0(0.0)$ & $0(0.0)$ & $2(4.0)$ & $2(1.3)$ \\
\hline Diploma & $0(0.0)$ & $0(0.0)$ & $19(38.0)$ & $19(12.7)$ \\
\hline Bachelor's & $16(32.0)$ & $0(0.0)$ & $24(48.0)$ & 64 (42.7) \\
\hline Master's/MPhil/MB ChB & $18(36.0)$ & $46(92.0)$ & $5(10.0)$ & $45(30.0)$ \\
\hline $\mathrm{PhD} /$ Specialist & $3(6.0)$ & $2(4.0)$ & $0(0.0)$ & $5(3.3)$ \\
\hline \multicolumn{5}{|l|}{ Monthly income (GHథ) } \\
\hline Less than 1000 & $0(0.0)$ & $0(0.0)$ & $11(22.0)$ & $11(7.3)$ \\
\hline $1000-1999$ & $20(40.0)$ & $20(40.0)$ & $34(68.0)$ & $74(49.3)$ \\
\hline 2000 or more & $30(60.0)$ & $29(58.0)$ & $4(8.0)$ & $63(42.0)$ \\
\hline \multicolumn{5}{|l|}{ Length of practice (years) } \\
\hline Mean \pm Standard deviation & $8.3 \pm 4.9$ & $7.2 \pm 5.5$ & $7.2 \pm 6.3$ & $7.5 \pm 5.6$ \\
\hline $0-4$ & $10(20.0)$ & $22(44.0)$ & $20(40.0)$ & $52(34.7)$ \\
\hline $5-9$ & $19(38.0)$ & $14(28.0)$ & $19(38.0)$ & $52(34.7)$ \\
\hline $10+$ & $15(30.0)$ & $14(28.0)$ & $10(20.0)$ & 39 (26.0) \\
\hline Total & $50(100.0)$ & $50(100.0)$ & $50(100.0)$ & $150(100.0)$ \\
\hline
\end{tabular}

As shown in Figure 1, in Accra City, access to purchase copies of the national laws is difficult. It is only at the Government Printers Shop, from which one could purchase a copy of the national laws, a fact which is not known to all. Such a facility was not available to many in the regions. Law books and select copies of national laws are sold by street-side type of vendors on table tops on the grounds of the court houses and at the general post offices. Several private bookstores carry selected copies of national legislation for sale. This makes it difficult for interested parties to access the laws that affect their performance. During the field tests almost all respondents disagreed that they can easily download copies of Ghana's Public Health Laws. They however agreed (3.9) on a scale of 1 - 5 with 5 being the highest that University libraries have catalogues of Ghana's laws. While this is the case of the universities with dedicated law training programs such as the University of Ghana and Kwame Nkrumah University of Science and Technology, the same cannot be said of the other public and private universities, which do not run professional law training programs.

\subsection{Awareness of Public Health Laws and Prior Education}

We had speculated in our objective that awareness of public health law was dependent on prior training in public health law or medical ethics. Although there is a significantly weak correlation of about $19.6 \%(p<0.05)$ between highest education attained and the previous study of public health, there is about $57.5 \%$ correlation between previous study of public health law and whether respondents had a general idea what public health law ought to be. This outcome was highly significant at $0.01 \%(p<0.001)$. Table 2 below shows the distribution among the cohorts and Table 3 shows the distribution of the correlation between education and prior study of public health law and thus the appreciation for public health laws. The interesting outcome of this part of the study is that medical doctors seem to have a slightly higher level of previous study of public health $($ mean = 2.6) than nurses (mean = 2.4) and lawyers (mean = 2.0) using the scale in Figure 2 and in Table 2 below.

\subsection{Assessment of Knowledge-Awareness within the Public Health Ecosystem}

On assessment of knowledge and awareness of public health in general, doctors were more likely to agree 
Table 2. Correlation between education and prior study of public health and public health law.

\begin{tabular}{|c|c|c|c|c|c|}
\hline & $\begin{array}{l}\text { Highest } \\
\text { education } \\
\text { attained }\end{array}$ & $\begin{array}{l}\text { Previously } \\
\text { studied } \\
\text { public health }\end{array}$ & $\begin{array}{l}\text { Read about public } \\
\text { health generally but } \\
\text { not studied at School }\end{array}$ & $\begin{array}{c}\text { Previously } \\
\text { studied public } \\
\text { health law }\end{array}$ & $\begin{array}{l}\text { Have general idea } \\
\text { about what public } \\
\text { health law is }\end{array}$ \\
\hline Highest education attained & 1.000 & & & & \\
\hline Previously studied public health & $0.196^{*}$ & 1.000 & & & \\
\hline $\begin{array}{l}\text { Read about public health generally } \\
\text { but not studied at School }\end{array}$ & $0.333^{* * *}$ & $0.527^{* * *}$ & 1.000 & & \\
\hline Previously studied public health Law & $0.481^{* * * *}$ & $0.577^{* * * *}$ & $0.529^{* * * *}$ & 1.000 & \\
\hline Have general idea about what public health law is & $0.239^{* *}$ & $0.253^{* *}$ & $0.409^{* * *}$ & $0.575^{* * * *}$ & 1.000 \\
\hline
\end{tabular}

Note: Significant levels used were ${ }^{*} p<0.05,{ }^{* * *} p<0.01$ and ${ }^{* * *} p<0.001$.

Table 3. Knowledge of public health and public health law (comparing doctors and lawyers).

\begin{tabular}{|c|c|c|c|c|c|c|c|}
\hline Knowledge & \multicolumn{3}{|c|}{ Doctors } & \multicolumn{3}{|c|}{ Lawyers } & \multirow{2}{*}{$\begin{array}{l}\text { Wilcoxon } \\
\text { Rank sum }\end{array}$} \\
\hline $\begin{array}{c}(1=\text { Strongly disagree, } 2=\text { Disagree, } \\
3=\text { Neutral, } 4=\text { Agree, } 5=\text { Strongly agree })\end{array}$ & $\mathrm{n}$ & Mean & Rank sum & $\mathrm{n}$ & Mean & Rank sum & \\
\hline $\begin{array}{l}\text { Public health aims to: } \\
\text { Prevent diseases, prolong life, and promote health through } \\
\text { organized efforts of society and organizations }\end{array}$ & 50 & 4.9 & 2925.0 & 50 & 4.6 & 2125.0 & $p<0.001$ \\
\hline Ensure that when people are sick they see a doctor for medical care & 50 & 4.9 & 2900.0 & 50 & 4.6 & 2150.0 & $p<0.001$ \\
\hline Provide citizens with a good environment free from diseases and filth & 50 & 4.9 & 3075.0 & 50 & 4.5 & 1975.0 & $p<0.001$ \\
\hline $\begin{array}{l}\text { Public health concerns the preservation and codification of the } \\
\text { standards established for the prevention of diseases }\end{array}$ & 50 & 4.9 & 3125.0 & 50 & 4.4 & 1925.0 & $p<0.001$ \\
\hline $\begin{array}{l}\text { In a national emergency, public health needs may be superior to the } \\
\text { constitutional rights of the citizens even under a democratic government }\end{array}$ & 50 & 4.8 & 3225.0 & 50 & 4.3 & 1825.0 & $p<0.001$ \\
\hline $\begin{array}{l}\text { Criminal suspects may not be detained without probable cause, } \\
\text { but in public health, citizens with suspected contagious diseases } \\
\text { may be detained without confirmation or due process }\end{array}$ & 50 & 4.8 & 3250.0 & 50 & 4.2 & 1800.0 & $p<0.001$ \\
\hline $\begin{array}{l}\text { Ghana lacks the legal framework for public } \\
\text { health because Ghana does not have a public health } \\
\text { act which would have contained the composite framework }\end{array}$ & 50 & 4.3 & 2843.5 & 50 & 4.0 & 2206.5 & $p<0.01$ \\
\hline $\begin{array}{l}\text { Public health law: } \\
\text { Concerns the preservation and codification of the standards established } \\
\text { for the prevention of diseases, prolongation of life, promotion of health } \\
\text { and the enforcement against encroachment to the legal framework } \\
\text { affecting health and safety by regulating the conduct of society }\end{array}$ & 50 & 4.1 & 2675.5 & 50 & 4.0 & 2374.5 & $p<0.05$ \\
\hline $\begin{array}{c}\text { Consists of various statutes, acts, legislative and executive } \\
\text { instruments, by-laws of municipalities, policies and regulations } \\
\text { of ministries, departments and agencies, traditional law and } \\
\text { the common law or judge-made law }\end{array}$ & 50 & 4.1 & 2599.0 & 50 & 4.0 & 2451.0 & $p=0.347$ \\
\hline $\begin{array}{l}\text { Narrowly deals with aspects of law that concerns the } \\
\text { practice of medicine and healthcare delivery }\end{array}$ & 50 & 4.1 & 2622.5 & 49 & 4.0 & 2327.5 & $p=0.116$ \\
\hline
\end{tabular}

Note: Significant levels used were 5\% ( $p<0.05), 1 \%(p<0.01)$ and $0.1 \%(p<0.001)$ with exact $\mathrm{p}$-values shown otherwise.

strongly (mean $=4.9)$ with Winslow (1920) definition of public health that public health "aims to prevent diseases, prolong life, and promote health through organized efforts of society and organizations" when compared to the lawyers who also agreed to a high extent (mean $=4.6$ ). This difference however, which is also evident in their respective rank sums is highly significant at $0.1 \%$ under the Wilcoxon Rank sum test $(p<0.001)$ found in Table 3 and also higher among doctors against nurses in Table 4. 
Access to Public Health Laws

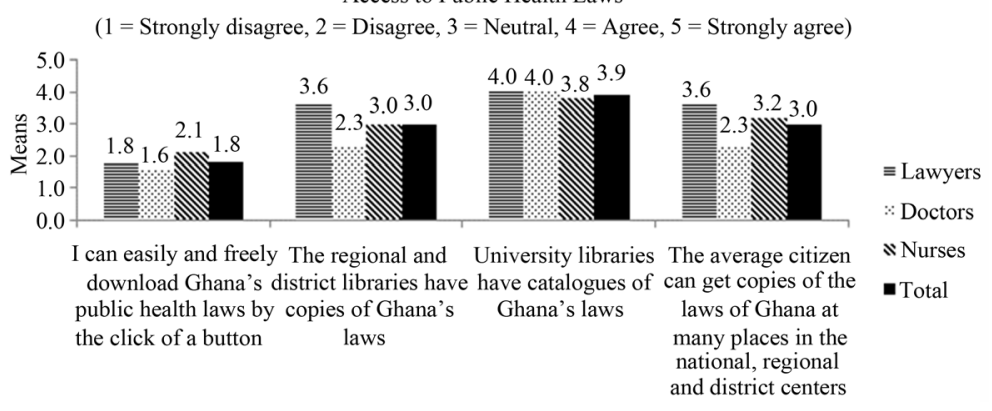

Figure 1. Assessment of access to public health laws.

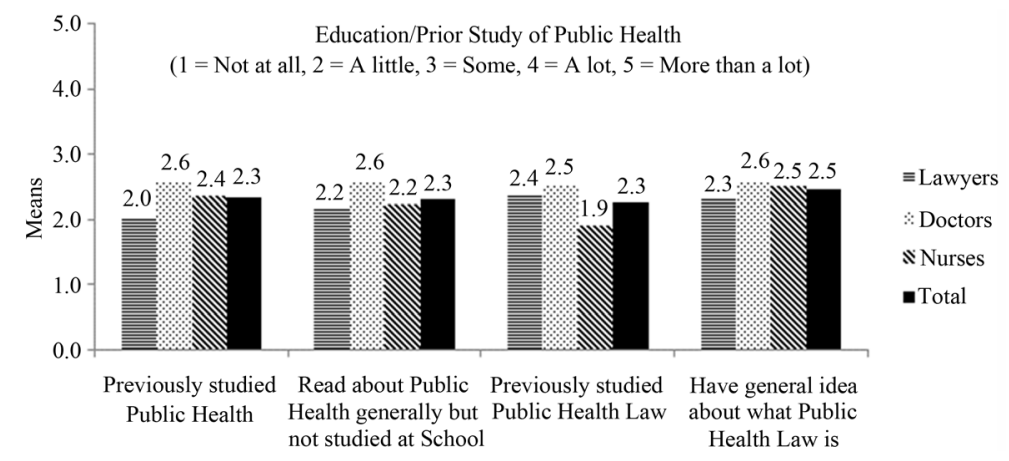

Figure 2. Education/prior study of public health. E.g. Doctors seem to have had a slightly higher level of previous study of public health (mean = 2.6) than nurses (mean $=2.4$ ) and lawyers (mean $=2.0$ ) using the above scale.

Table 4. Knowledge of public health and public health law (comparing doctors and nurses).

\begin{tabular}{|c|c|c|c|c|c|c|c|}
\hline Knowledge & \multicolumn{3}{|c|}{ Doctors } & \multicolumn{3}{|c|}{ Nurses } & \multirow{2}{*}{$\begin{array}{l}\text { Wilcoxon } \\
\text { Rank sum }\end{array}$} \\
\hline $\begin{array}{l}(1=\text { Strongly disagree, } 2=\text { Disagree, } 3=\text { Neutral, } \\
4=\text { Agree, } 5=\text { Strongly agree })\end{array}$ & $\mathrm{n}$ & Mean & Rank sum & $\mathrm{n}$ & Mean & Rank sum & \\
\hline $\begin{array}{l}\text { Public health aims to: } \\
\text { Prevent diseases, prolong life, and promote health } \\
\text { through organized efforts of society and organizations }\end{array}$ & 50 & 4.9 & 2700.0 & 50 & 4.8 & 2350.0 & $p<0.05$ \\
\hline Ensure that when people are sick they see a doctor for medical care & 50 & 4.9 & 2804.5 & 50 & 4.6 & 2245.5 & $p<0.01$ \\
\hline Provide citizens with a good environment free from diseases and filth & 50 & 4.9 & 2652.0 & 49 & 4.8 & 2298.0 & $p=0.078$ \\
\hline $\begin{array}{l}\text { Public health concerns the preservation and codification of the } \\
\text { standards established for the prevention of diseases }\end{array}$ & 50 & 4.9 & 2950.0 & 50 & 4.6 & 2100.0 & $p<0.001$ \\
\hline $\begin{array}{l}\text { In a national emergency, public health needs may be superior to the } \\
\text { constitutional rights of the citizens even under a democratic government }\end{array}$ & 50 & 4.8 & 2865.0 & 49 & 4.5 & 2085.0 & $p<0.001$ \\
\hline $\begin{array}{l}\text { Criminal suspects may not be detained without probable cause, } \\
\text { but in public health, citizens with suspected contagious diseases } \\
\text { may be detained without confirmation or due process }\end{array}$ & 50 & 4.8 & 3150.0 & 50 & 3.9 & 1900.0 & $p<0.001$ \\
\hline $\begin{array}{l}\text { Ghana lacks the legal framework for public health because } \\
\text { Ghana does not have a Public Health Act which } \\
\text { would have contained the composite framework }\end{array}$ & 50 & 4.3 & 2885.0 & 50 & 3.6 & 2165.0 & $p<0.01$ \\
\hline $\begin{array}{l}\text { Public health law: } \\
\text { Concerns the preservation and codification of the standards established for the } \\
\text { prevention of diseases, prolongation of life, promotion of health and the en- } \\
\text { forcement against encroachment to the legal framework } \\
\text { affecting health and safety by regulating the conduct of society }\end{array}$ & 50 & 4.1 & 2157.5 & 50 & 4.4 & 2892.5 & $p<0.01$ \\
\hline $\begin{array}{l}\text { Consists of various statutes, acts, legislative and executive instruments, } \\
\text { by-laws of municipalities, policies and regulations of ministries, departments } \\
\text { and agencies, traditional law and the common law or judge-made law }\end{array}$ & 50 & 4.1 & 2603.0 & 50 & 4.0 & 2447.0 & $p=0.505$ \\
\hline $\begin{array}{l}\text { Narrowly deals with aspects of law that concerns } \\
\text { the practice of medicine and healthcare delivery }\end{array}$ & 50 & 4.1 & 2497.5 & 50 & 4.0 & 2552.5 & $p=0.812$ \\
\hline
\end{tabular}

Note: Significant levels used were 5\% $(p<0.05), 1 \%(p<0.01)$ and $0.1 \%(p<0.001)$ with exact $p$-values shown otherwise. 


\subsection{Assessment of Hostilities among the Professions}

We investigated whether there were other emotional or egoistic reasons why, for example, there were professional hostilities between lawyers and medical doctors in Ghana by looking at how each of the three members of the cohort views the other. We compared doctors and nurses to assess their views. In this comparison, both doctors and nurses disagreed that either there were too many Latin words or too many laws to interests them. The outcome in the six areas we looked as proxies to underlining hostilities by the medical profession towards lawyers was significant. However, as in Figure 3, when we asked lawyers to rate their relationships towards doctors and nurses, the outcome was different. The lawyers though very sanguine about their relationship with doctors and nurses, on a scale of 1 to 4 with 5 being the highest, 4 said they did not need to understand public health laws in order to do their work. Doctors were very high in their response that they did not need to understand law in order to do their job. Nurses were more accommodating with 3.7 of them making similar statement, all of which were significant (Table 5).

\subsection{Benefits of Knowledge and Skills in Public Health Law}

Almost all the professions agreed that they were better off with knowledge and skills in public health law than without. See Table 6 below.

\section{Table 5. Hostility towards law (comparing doctors and nurses).}

\begin{tabular}{cccccccc}
\hline Reason & \multicolumn{3}{c}{ Doctors } & & Nurses & Wilcoxon \\
\hline $\begin{array}{c}\text { (1 = Strongly disagree, 2 = Disagree, } \\
\text { 3 = Neutral, 4 = Agree, 5 = Strongly agree })\end{array}$ & $\mathrm{n}$ & Mean & Rank sum & $\mathrm{n}$ & Mean & Rank sum & Rank sum \\
Too many long Latin words & 50 & 1.1 & 1764.0 & 50 & 2.1 & 3286.0 & $p<0.001$ \\
Too many laws, regulations, rules, statutes to interest me & 50 & 1.1 & 1693.5 & 50 & 2.1 & 3356.5 & $p<0.001$ \\
The law is written to confuse and trick non-lawyers & 50 & 1.1 & 1862.5 & 50 & 1.8 & 3187.5 & $p<0.001$ \\
I don’t like lawyers so I don't even bother & 50 & 1.1 & 2010.0 & 50 & 1.8 & 3040.0 & $p<0.001$ \\
I don't really need to understand law to do & 50 & 4.7 & 3137.5 & 50 & 3.7 & 1912.5 & $p<0.001$ \\
my job well as a medical doctor or a nurse & & & & & &
\end{tabular}

Note: Significant levels used were $5 \%(p<0.05), 1 \%(p<0.01)$ and $0.1 \%(p<0.001)$ with exact $p$-values shown otherwise.

Table 6. Benefits of knowledge and skills in public health law.

\begin{tabular}{|c|c|c|c|c|c|c|c|}
\hline Reason & \multicolumn{3}{|c|}{ Doctors } & \multicolumn{3}{|c|}{ Lawyers } & \multirow{2}{*}{$\begin{array}{l}\text { Wilcoxon } \\
\text { Rank sum }\end{array}$} \\
\hline $\begin{array}{c}(1 \text { = Strongly disagree, } 2=\text { Disagree, } 3=\text { Neutral, } \\
4=\text { Agree, } 5=\text { Strongly agree })\end{array}$ & $\mathrm{n}$ & Mean & Rank sum & $\mathrm{n}$ & Mean & Rank sum & \\
\hline Empowering and allows me to do my job better & 50 & 3.9 & 2623.5 & 49 & 3.8 & 2326.5 & $p=0.113$ \\
\hline Improves personal and professional efficiencies & 50 & 3.9 & 2622.0 & 50 & 3.8 & 2428.0 & $p=0.199$ \\
\hline Removes doubt and conflict & 50 & 3.0 & 2365.0 & 50 & 3.1 & 2685.0 & $p=0.189$ \\
\hline Clients/patients get the best of me & 49 & 3.9 & 2339.0 & 50 & 4.0 & 2611.0 & $p=0.277$ \\
\hline \multirow[t]{2}{*}{ Reduces feelings of inadequacy and stress } & 49 & 3.0 & 2389.0 & 50 & 3.0 & 2561.0 & $p=0.615$ \\
\hline & & \multicolumn{2}{|c|}{ Doctors } & \multicolumn{3}{|c|}{ Nurses } & \\
\hline Empowering and allows me to do my job better & 50 & 3.9 & 2755.0 & 50 & 3.6 & 2295.0 & $p<0.05$ \\
\hline Improves personal and professional efficiencies & 50 & 3.9 & 2465.5 & 50 & 3.9 & 2584.5 & $p=0.608$ \\
\hline Removes doubt and conflict & 50 & 3.0 & 2201.5 & 50 & 3.4 & 2848.5 & $p<0.05$ \\
\hline Clients/patients get the best of me & 49 & 3.9 & 2413.5 & 49 & 3.9 & 2437.5 & $p=0.917$ \\
\hline Reduces feelings of inadequacy and stress & 49 & 3.0 & 2613.5 & 50 & 2.8 & 2336.5 & $p=0.226$ \\
\hline
\end{tabular}

Note: Significant levels used were $5 \%(p<0.05), 1 \%(p<0.01)$ and $0.1 \%(p<0.001)$ with exact $p$-values shown otherwise. 


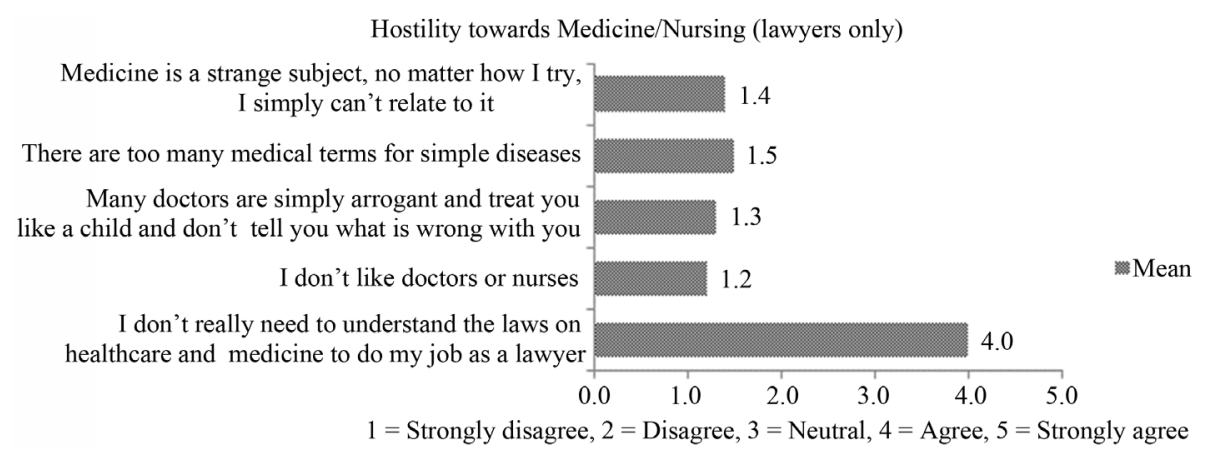

Figure 3. Hostility towards doctors and nurses.

\section{Discussion and Conclusion}

There cannot be a credible public health program in a given nation if the key stakeholders do not appreciate the importance of the laws that bind them together. In this study, we felt that for there to be a good model for public healthcare delivery system, doctors, nurses and lawyers needed to have the basic functional knowledge, skills and abilities in public health law. For example, the banning of cigarette smoking from public places and restaurants in Ghana and elsewhere is largely due to the collaboration between medical doctors, scientists, public health researchers, geneticists and lawyers. It is this kind of collaboration which is required for advancing the gains in global health programs and the protections we as a community need to do in order to safeguard the public health of the communities. Though there is cost involved in dissemination of such information, a web based source of supply provides an economically viable alternative. In the ICT age of data collection, storage and mining for public health research, it is important for stakeholders who are key guidance of the public health and individual liberties to understand and appreciated the interconnectedness of the legal framework affecting the health of the communities in order to be effective players within such ecosystem.

\section{References}

Braye, S., \& Preston-Shoot, M. (2005). Emerging from out of the Shadows? Service User and Carer Involvement in Systematic Reviews. Evidence \& Policy, 1, 173-193. http://dx.doi.org/10.1332/1744264053730743

Dickson, D. (1997). Law, Ethics and Social Work with the Elderly: Self-Determination. Journal of Law and Social Work, 7 , 105-155

Falkiner, L. (2003). Inventory of Disaster Management Education in Major Canadian Universities (Paper Series No. 30, pp. 1-9). Institute for Catastrophic Loss Reduction.

Johns, R., Braye, S., \& Preston-Shoot, M. (2005). Law Teaching in Social Work Education: Promoting Social Cohesion. Paper Presented at the IFSW/EASSW Conference "Social Work, 2005”, Lefkosia, 21-23 May 2005,

Norman, I. D., Aikins, M., Binka. F., Banyubala, N. D., \& Edwin, A. K. (2012). The Constitutional Mandate for Judge-Made-Law and Judicial Activism: A Case Study of the Matter of Elizabeth Vaah v. Lister Hospital and Fertility Centre. The Open Ethics Journal, 6, 1-7.

Norman, I. D., Aikins, M., \& Binka, F. (2011). The Medico-Legal Prerequisite for Initiating Quarantine and Isolation Practices in Public Health Emergency Management in Hospitals in Ghana. Ghana Medical Journal, 45, 1-7.

Tetrick, L. E. (2003). Quick, J. C. (Eds.). Handbook of Occupational Health Psychology (pp: ix). Washington, DC: American Psychological Association Press.

UNDP (2008). UNDP Global Report, Reducing Disaster Risk: A Challenge for Development. Nairobi: The Secretariat, International Strategy for Disaster Risk, Reduction.

Winslow, C. E. A. (1920). In Encyclopedia of Public Health (Ed.), Lester Breslow. Boston: Gale Group, Inc. 
Scientific Research Publishing (SCIRP) is one of the largest Open Access journal publishers. It is currently publishing more than 200 open access, online, peer-reviewed journals covering a wide range of academic disciplines. SCIRP serves the worldwide academic communities and contributes to the progress and application of science with its publication.

Other selected journals from SCIRP are listed as below. Submit your manuscript to us via either submit@scirp.org or Online Submission Portal.
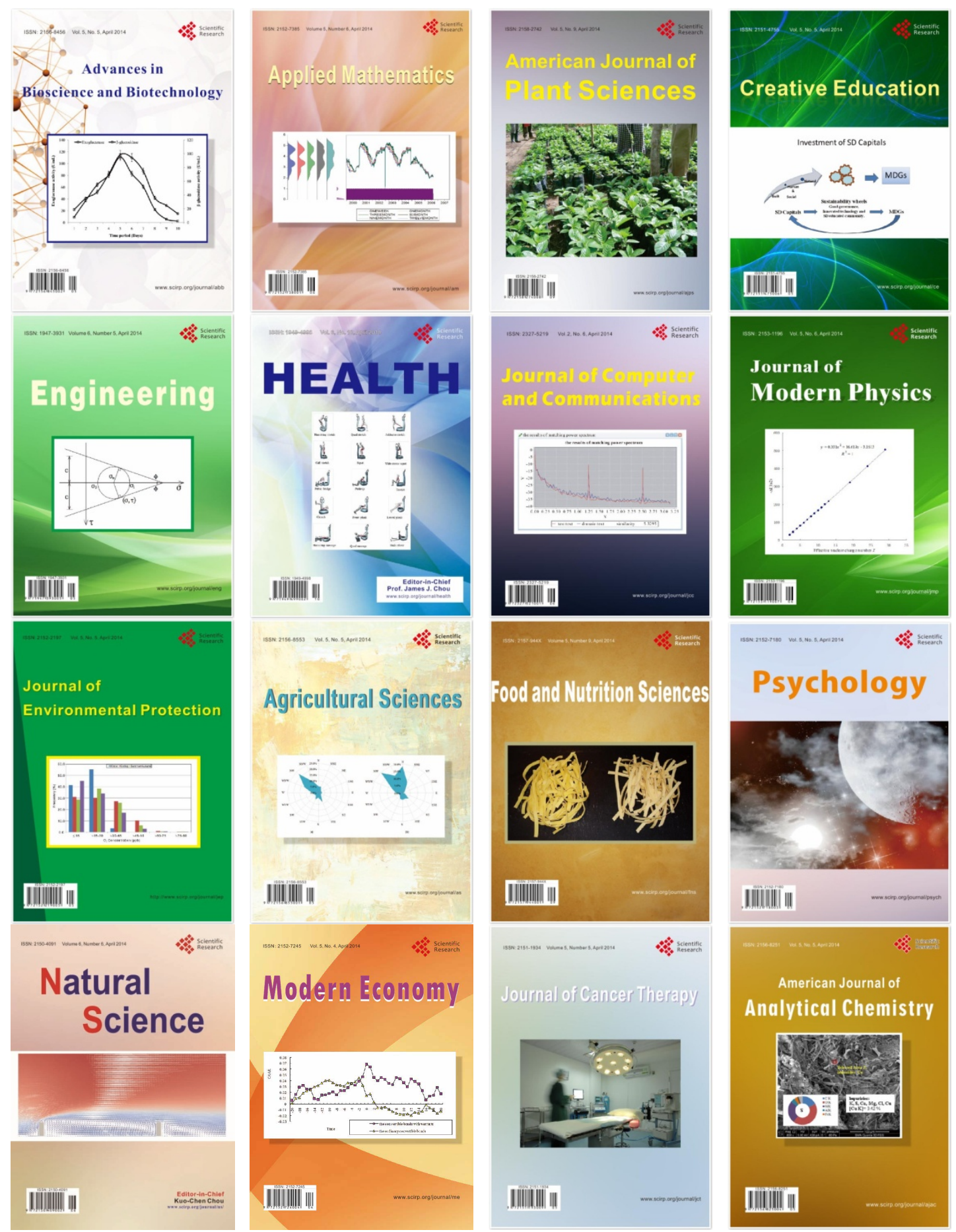